\title{
STRATEGI BLENDED LEARNING UNTUK PENINGKATAN KEMANDIRIAN BELAJAR DAN KEMAMPUAN CRITICAL THINKING MAHASISWA DI ERA DIGITAL
}

\author{
Oleh : \\ Annisa Ratna Sari \\ StafPengajar Jurusan P. Akuntansi Universitas Negeri Yogyakarta
}

\begin{abstract}
Abstrak
Tujuan dilaksanakannya penelitian ini adalah: (1) Mengetahui deskripsi implementasi strategi Blended Learning dalam meningkatkan prestasi belajar mahasiswa (2) Mengetahui peningkatan kemandirian belajar mahasiswa melalui pengimplementasian strategi Blended Learning (3) Mengetahui peningkatan kemampuan Critical Thinking mahasiswa melalui pengimplementasian strategi Blended Learning.

Penelitian ini dilaksanakan di Program Studi Pendidikan Akuntansi FE UNYpada tahun akademik 2011/2012. Penelitian ini merupakan penelitian tindakan kelas dengan pendekatan model Kemmis-Taggart. Penelitian ini didahului dengan mengembangkan perangkat pembelajaran Blended Learning sebagai upaya untuk meningkatkan Kemandirian Belajar, Critical Thinking, maupun prestasi belajar mahasiswa. Tahap-tahap penelitian tiap siklus meliputi: perencanaan, pelaksanaan tindakan, observasi, dan refleksi. Subyek penelitian ini adalah mahasiswa yang mengambil mata kuliah Evaluasi Pembelajaran Akuntansi. Metode pengumpulan data dengan observasi, dan tes atau pemberian tugas/kuis untuk mengetahui kualitas proses dan hasil pembelajaran. Analisis data menggunakan analisis deskriptif.

Strategi pembelajaran Blended Learning terbukti berhasil meningkatkan Kemandirian Belajar, Critical Thinking, maupun prestasi belajar dari mahasiswa terhadap perkuliahan Evaluasi Pembelajaran Akuntansi. Hal ini didasarkan pada terjadinya: (1) peningkatan kemampuan mahasiswa untuk belajar mandiri antara sebelum implementasi Strategi Blended Learning yaitu sebesar 14,3\%, dan setelah siklus terakhir pengimplementasian Strategi Blended Learning adalah sebesar $85,7 \%$ (2) peningkatan kemampuan mahasiswa untuk berpikir kritis antara sebelum implementasi Strategi Blended Learning yaitu sebesar 19,3\%, dan setelah siklus terakhir pengimplementasian Strategi Blended Learning adalah sebesar 88,6\% (3) peningkatan Prestasi Belajar mahasiswa dimana terdapat 92,9\% mahasiswa yang mendapatkan nilai lebih besar sama dengan 75 untuk komponen tugas dan partisipasi, dan 78,6\% mahasiswa yang mendapatkan nilai lebih besar sama dengan 75 untuk komponen UAS.
\end{abstract}

Kata kunci: blended learning, kemandirian belajar, critical thinking, prestasi belajar 


\section{A. PENDAhULUAN}

Pada era digital dewasa ini, manusia dapat belajar kapan saja dan dimana saja. Dalam hal ini, pembelajaran bersifat otentik dan berbasis individu. Akan tetapi, strategi pembelajaran yang populer saat ini di Indonesia adalah pembelajaran tradisional, yaitu pembelajaran berbasis kelas (klasikal) dengan menggunakan metode ceramah. Dalam pembelajaran klasikal, proses belajar mahasiswa terikat oleh dimensi ruang dan waktu, artinya mahasiswa harus berada dalam ruang dan waktu yang sama dengan teman sekelas dan dosennya untuk melakukan kegiatan pembelajaran. Oleh karena itu, perlu dicari alternatif untuk pembelajaran klasikal yang bisa mengatasi masalah tersebut tanpa menghilangkan perasaan ikatan sosial antara mahasiswa dengan teman sekelasnya maupun antara mahasiswa dengan dosennya. Apabila ceramah menjadi satu-satunya metode pembelajaran, kemampuan Critical Thinking mahasiswa menjadi kurang terasah karena mahasiswa tidak terbiasa untuk berpikir di luar konteks yang disampaikan oleh dosen dan menjadi pasif dalam memilih sumber belajar tambahan di luar sumber belajar yang disediakan oleh dosen. Padahal dosen tidak seharusnya menjadi satu-satunya sumber belajar, terutama di era digital dewasa ini, dimana sumber belajar bisa diperoleh dengan relatif mudah melalui bantuan teknologi informasi.

Tidak dapat dipungkiri bahwa era digital memberikan dampak yang positif terhadap dunia kependidikan, sebagai contoh adalah munculnya alternatif-alternatif sumber belajar dan media pembelajaran. Pembelajaran yang dulunya hanya dapat dilakukan di kelas saja, kini sudah mulai dapat digantikan dengan cara online. Pembelajaran Online merupakan pelaksanaan belajar mengajar yang sepenuhnya dilakukan dengan bantuan teknologi internet dan tidak membutuhkan adanya kegiatan face to face. Dalam pembelajaran ini, siswa dapat belajar darimana saja dan dapat dilakukan secara synchronous (langsung) ataupun asynchronous (tidak langsung).

Selain pembelajaran online, terdapat pembelajaran blended learning. Pembelajaran blended learning merupakan jenis pembelajaran yang menggabungkan pengajaran klasikal (face to face) dengan pengajaran online. Blended learning menawarkan fleksibilitas dalam hal waktu, tempat, dan variasi metode pembelajaran yang lebih banyak dibandingkan metode online maupun face to face.

Berdasarkan hasil pengamatan peneliti terhadap mahasiswa Pendidikan Akuntansi kelas Internasional yang pada tahun ajaran 2011/2012 ini sedang mengambil mata kuliah Evaluasi Pembelajaran Akuntansi dengan menggunakan pembelajaran tradisional, mahasiswa terlihat mencari sumber belajar selain yang sudah disediakan oleh dosen. Berdasarkan hasil observasi peneliti dalam tiga kali pelaksanaan diskusi di dalam kelas yang dilakukan oleh mahasiswa, tidak semua mahasiswa terlibat secara aktif untuk mengeluarkan pendapat berdasarkan tema yang disediakan oleh dosen. Dari 14 mahasiswa, hanya 1 mahasiswa yang terlihat mengerti tentang praktik nyata evaluasi pembelajaran di sekolah. Hal ini menunjukkan bahwa mahasiswa belum mampu untuk belajar mandiri tentang hal-hal yang berkaitan dengan tema/topik perkuliahan. 
Selain itu, fenomena ini juga menunjukkan bahwa mahasiswa belum mampu berpikir secara kritis tentang pelaksanaan evaluasi pembelajaran secara umum yang terjadi di sekitarnya.

Bermacam masalah yang telah diuraikan diatas memerlukan alternatif pemecahan yang handal dan segera agar tidak mengganggu proses dan output pendidikan. Strategi pembelajaran blended learning ditawarkan oleh peneliti sebagai solusi mengingat (1) strategi ini menawarkan banyak alternatif sumber belajar bagi siswa di luar bahan yang sudah diberikan oleh guru melalui penggunaan teknologi informasi dan dapat dimanfaatkan untuk mensuport kekurangan pembelajaran tradisional, (2) UNY sudah memiliki jaringan wifi yang merata di tiap fakultas yang dapat dimanfaatkan oleh seluruh pihak di lingkungan UNY, baik itu dosen, mahasiswa maupun staff, (3) banyak mahasiswa yang sudah membawa laptop untuk menunjang kegiatan belajar mengajar maupun guna menyelesaikan tugas di kampus. Pertimbangan nomor 2 dan 3 diatas menunjukkan dukungan teknis yang ada untuk menjembatani terlaksananya strategi blended learning, sedangkan pertimbangan nomor 1 diatas diharapkan dapat menjadi salah satu sarana pencetus kemandirian belajar dan critical thinking mahasiswa. Oleh karena itu dalam penelitian ini, peneliti memilih judul: "Strategi Blended Learning untuk Peningkatan Kemandirian Belajar dan Kemampuan Critical Thinking Mahasiswa di Era Digital".

a. Strategi Blended Learning

Blended learning pada dasarnya adalah suatu sistem belajar yang memadukan antara belajar secara face to face (bertemu muka/klasikal) dengan belajar secara online (melalui penggunaan fasilitas/media internet). Ada beberapa pendapat yang berbeda dari para ahli yang menentukan prosentase untuk masing masing cara, baik itu yang sifatnya face to face atau online. Sloan (dalam Avgerinou, 2008) menyebutkan bahwa sebuah pembelajaran dikatakan menggunakan strategi Blended Learning apabila 30-80\% dari desain dan implementasi pembelajaran baik dalam hal isi maupun penyampaiannya dilakukan secara online.

Akhmad Faizal menjelaskan bahwa dalam pembelajaran Blended Learning, siswa tidak hanya mengandalkan materi yang diberikan oleh guru, tetapi dapat mencari materi dalam berbagai cara, antara lain, mencari ke perpustakaan, menanyakan kepada teman kelas atau teman saat online, membuka website, mencari materi belajar melalui search engine, portal, maupun blog, atau bisa juga dengan media media lain berupa software pembelajaran dan juga tutorial pembelajaran.

Graham (dalam Avgerinou, 2008) menjelaskan tiga alasan penting kenapa seorang pengajar lebih memilih mengimplementasikan Blended Learning dibandingkan pembelajaran online maupun klasikal, yaitu: pedagogy yang lebih baik, meningkatnya akses dan fleksibilitas, serta meningkatnya biaya-manfaat. Tabel di bawah ini dapat menunjukkan perbandingan kekuatan dan kelemahan dari pelaksanaan 
pembelajaran tradisional/face to face dan online yang dijadikan pijakan pendapat Graham diatas:

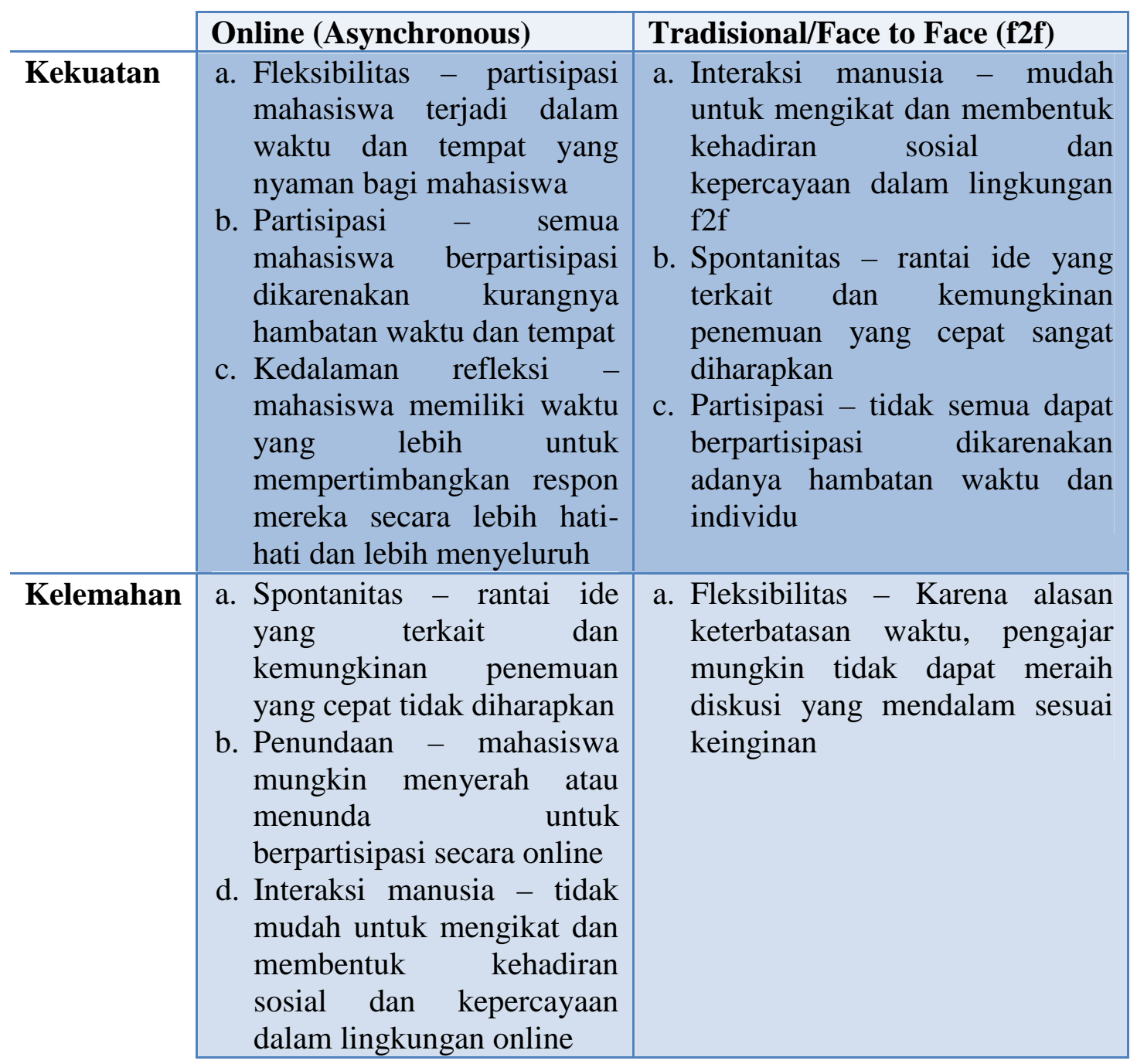

Tabel 1. Perbandingan kekuatan dan kelemahan antara pembelajaran online dan pembelajaran tradisional/face to face

b. Kemandirian Belajar

Kemandirian belajar menunjukkan bahwa seorang siswa mempunyai rasa tanggung jawab terhadap keberhasilannya dalam belajar. Hal ini tidak lepas dari telah tercapainya kematangan dalam diri siswa sehingga dia menyadari tujuan dari belajar. Hargis (dalam Hidayati dan Listiyani, 2010) mendefinisikan kemandirian belajar sebagai self regulated learning yakni upaya memperdalam dan memanipulasi jaringan asosiatif dalam suatu bidang tertentu, dan memantau serta meningkatkan proses pendalaman yang bersangkutan.

Menurut Knowles (dalam Fisher, King, danTague; 2001), Kemandirian Belajar diartikan sebagai sebuah proses dimana seorang individu mampu: 
1) Mengambil inisiatif, baik dengan atau tanpa bantuan orang lain, untuk mendiagnosa kebutuhan belajarnya

2) Memformulasikan tujuan belajar

3) Mengidentifikasi sumber belajar, baik berupa manusia ataupun barang/bahan

4) Memilih dan mengimplementasikan strategi belajar yang cocok untuk dirinya

5) Mengevaluasi hasil belajarnya

Menurut Kozma, Belle, William (dalam Pannen dan Sekarwinahya, 1994: 59) terdapat beberapa dampak positif dari kemandirian belajar bagi mahasiswa, yaitu: mahasiswa akan merasakan tingkat kepuasan yang tinggi, mempunyai minat dan perhatian yang tidak terputus-putus, dan mempunyai kepercayaan diri yang lebih kuat dibandingkan dengan mahasiswa yang hanya belajar secara pasif (menerima saja).

c. Critical Thinking

Richard Paul dan Linda Elder (2008) dalam sebuah makalah berjudul "The Miniature Guide to Critical Thinking Concepts and Tools" mendefinisikan Critical Thinking sebagai sebuah seni berpikir analisis dan evaluasi yang mempunyai tujuan untuk memperbaiki. Sedangkan Scriver dan Paul menyebutkan bahwa Critical Thinking merupakan sebuah standar intelektual yang bagus sebagai syarat untuk berpartisipasi secara penuh dalam ranah sosial, ekonomi dan kehidupan politik di lingkungan dimana kita tinggal.

Secara singkat, Critical thinking adalah kemampuan seseorang untuk dirinya sendiri, mendisiplinkan dirinya, memonitor dirinya, dan mampu berpikir untuk mengoreksi dirinya sendiri; dimana secara rutin mereka akan mengaplikasikan standar-standar intelektual pada elemenelemen cara berpikir dengan tujuan untuk membentuk atribut intelektual (Paul dan Elder, 2008).

Ennis (dalam Stenberg dan Baron; 1985) menyebutkan bahwa seseorang dapat dikatakan mempunyai kemampuan berpikir kritis tatkala orang tersebut mempunyai ciri-ciri sebagai berikut:

1. Berpikiran terbuka

2. Mengambil sikap ketika bukti dan alasan sudah cukup

3. Mempertimbangkan keseluruhan situasi

4. Membekali diri dengan informasi

5. Mencari kebenaran/keakuratan sebanyak-banyaknya

6. Menyelesaikan masalah dengan sistematis dan menyeluruh

7. Mencari alternatif-alternatif

8. Mencari alasan/sebab

9. Mencari pernyataan yang jelas dari sebuah permasalahan

10. Mengingat-ingat hal yang utama/mendasar

11. Mempergunakan sumber yang kredibel dan menyebutkannya 
12. Berusaha relevan dengan ide utama

13. Sensitif terhadap perasaan, tingkat pengetahuan, dan tingkat kemampuan orang lain

\section{B. METODE PENELITIAN}

\section{Desain Penelitian}

Penelitian ini merupakan penelitian tindakan kelas. Dalam penelitian ini, model Penelitian Tindakan Kelas yang diadopsi merupakan model penelitian tindakan dari Kemmis dan McTaggart. Apabila dicermati, model yang dikemukakan oleh Kemmis \& McTaggart pada hakekatnya berupa rangkaian perangkat-perangkat atau untaian-untaian dimana dalam satu rangkaian terdiri dari empat komponen, yaitu: perencanaan, tindakan, pengamatan dan refleksi. Rangkaian perangkat tersebut dipandang sebagai satu siklus.

Penelitian tindakan kelas ini direncanakan akan dilaksanakan dalam beberapa siklus, dimana untuk tiap-tiap siklusnya terdiri dari empat tahapan yaitu perencanaan, pelaksanaan, observasi, dan refleksi. Kegiatan pembelajaran dengan strategi pembelajaran Blended Learning ini akan berlanjut ke siklus berikutnya apabila indikator keberhasilan belum tercapai. Penelitian tindakan kelas ini tidak ditentukan akan dilaksanakan dalam jumlah siklus tertentu, tetapi didasarkan pada hasil peningkatan Critical Thinking dan Kemandirian Belajar mahasiswa melalui implementasi strategi pembelajaran. Hal ini senada dengan apa yang diungkapkan oleh Suharsimi Arikunto (2008), yaitu banyaknya siklus penelitian dalam penelitian tindakan kelas tergantung pada pencapaian tolok ukur, namun sebaiknya tidak kurang dari dua siklus.

\section{Subyek dan Obyek Penelitian}

Penelitian ini merupakan penelitian tindakan kelas yang dilakukan terhadap semua mahasiswa Program Studi Pendidikan Akuntansi kelas Internasional pada Fakultas Ekonomi Universitas Negeri Yogyakarta tahun ajaran 2010/2011 yang mengambil mata kuliah Evaluasi Pembelajaran Akuntansi. Seluruh mahasiswa pada kelas tersebut yang berjumlah 14 orang akan dijadikan subyek penelitian. Sedangkan obyek penelitian ini adalah strategi Blended Learning untuk peningkatan Kemandirian Belajar dan Kemampuan Critical Thinking mahasiswa.

\section{Teknik Pengumpulan Data}

Penelitian ini akan dilaksanakan selama bulan April-Juni 2012, dimana data pra penelitian akan dikumpulkan pada minggu ke-4 bulan April 2012. Data pra penelitian digunakan untuk mendapatkan informasi terkini untuk pelaksanaan pembelajaran tradisional (face to face). Siklus satu akan dilaksanakan pada bulan Mei 2012 minggu ke-1, siklus dua akan dilaksanakan pada bulan Mei minggu ke-2, dan siklus tiga akan dilaksanakan pada bulan Mei minggu ke-3. Teknik pengumpulan data penelitian akan dilakukan melalui dokumentasi dan observasi. 


\section{Teknik Analisis Data}

Penelitian ini merupakan penelitian kualitatif sehingga perlu dilakukan uji kredibilitas atau uji kepercayaan terhadap data hasil penelitian kualitatif. Teknik yang akan digunakan adalah dengan menggunakan triangulasi data.

Data hasil belajar mahasiswa akan dianalisis menggunakan teknik statistik deskripstif. Data hasil belajar mahasiswa ini akan digunakan untuk mengevaluasi keberhasilan pelaksanaan strategi Blended Learning melalui adanya perubahan hasil belajar mahasiswa. Data hasil observasi Kemandirian Belajar, dan Critical Thinking akan dianalisis secara kualitatif.

\section{HASIL PENELITIAN DAN PEMBAHASAN}

Dilihat dari segi proses, pembelajaran dikatakan berhasil dan berkualitas jika seluruhnya atau minimal 75\% siswa terlibat aktif dan menunjukkan kegairahan belajar yang tinggi, semangat belajar yang besar, dan rasa percaya diri yang tinggi dan dari segi hasil proses pembentukan kompetensi dapat dikatakan berhasil apabila terjadi perubahan perilaku yang positif pada diri siswa seluruhnya atau minimal $75 \%$ sesuai dengan kompetensi dasar (Mulyasa, 2006: 101-102). Jadi pada penelitian ini, implementasi strategi Blended Learning dikatakan berhasil ketika minimal 75\% dari jumlah keseluruhan siswa telah memiliki Kemandirian dalam Belajar, kemampuan Critical Thinking, dan memperoleh prestasi belajar minimal 75 untuk nilai angka, atau B+ untuk nilai huruf.

Berdasarkan pengimplementasian Strategi Blended Learning dalam pembelajaran didapatkan hasil-hasil sebagai berikut:

\section{Aspek Kemandirian Belajar}

Terdapat 5 kriteria yang digunakan untuk mengukur aspek Kemandirian Belajar mahasiswa. Kriteria-kriteria tersebut kemudian digunakan sebagai pedoman untuk menilai jumlah mahasiswa yang mempunyai Kemandirian Belajar antara sebelum penelitian, penelitian siklus 1, penelitian siklus 2, dan penelitian siklus 3 .

\begin{tabular}{|c|c|c|c|c|c|c|c|c|}
\hline \multirow{2}{*}{ KRITERIA } & \multicolumn{2}{c|}{ Pra-PTK } & \multicolumn{2}{c|}{ Siklus 1 } & \multicolumn{2}{c|}{ Siklus 2 } & \multicolumn{2}{c|}{ Siklus 3 } \\
\cline { 2 - 9 } & $\sum$ & $\mathbf{\%}$ & $\sum$ & $\mathbf{\%}$ & $\sum$ & $\mathbf{\%}$ & $\sum$ & $\mathbf{\%}$ \\
\hline $\begin{array}{l}\text { 1. Mengambil inisiatif, } \\
\text { baik dengan atau tanpa } \\
\text { bantuan orang lain, } \\
\text { untuk mendiagnosa } \\
\text { kebutuhan belajarnya }\end{array}$ & 2 & $14,3 \%$ & 6 & $42,9 \%$ & 10 & $71,4 \%$ & 12 & $85,7 \%$ \\
\hline $\begin{array}{l}\text { 2. Memformulasikan } \\
\text { tujuan belajar }\end{array}$ & 2 & $14,3 \%$ & 6 & $42,9 \%$ & 10 & $71,4 \%$ & 12 & $85,7 \%$ \\
\hline $\begin{array}{l}\text { 3. Mengidentifikasi } \\
\text { sumber belajar, baik } \\
\text { berupa manusia } \\
\text { ataupun barang/bahan }\end{array}$ & 2 & $14,3 \%$ & 6 & $42,9 \%$ & 12 & $85,7 \%$ & 13 & $92,9 \%$ \\
\hline 4. Mampu untuk memilih & 2 & $14,3 \%$ & 6 & $42,9 \%$ & 12 & $85,7 \%$ & 12 & $85,7 \%$ \\
\hline
\end{tabular}




\begin{tabular}{|l|c|c|c|c|c|c|c|c|}
\hline \multirow{2}{*}{ KRITERIA } & \multicolumn{2}{|c|}{ Pra-PTK } & \multicolumn{2}{c|}{ Siklus 1 } & \multicolumn{2}{c|}{ Siklus 2 } & \multicolumn{2}{c|}{ Siklus 3 } \\
\cline { 2 - 8 } & $\sum$ & $\mathbf{\%}$ & $\sum$ & $\mathbf{\%}$ & $\sum$ & $\mathbf{\%}$ & $\sum$ & $\mathbf{\%}$ \\
\hline $\begin{array}{l}\text { dan } \\
\text { mengimplementasikan } \\
\text { strategi belajar yang } \\
\text { cocok untuk dirinya }\end{array}$ & & & & & & & & \\
\hline $\begin{array}{l}\text { 5. Mengevaluasi hasil } \\
\text { belajarnya }\end{array}$ & 2 & $14,3 \%$ & 6 & $42,9 \%$ & 10 & $71,4 \%$ & 11 & $78,6 \%$ \\
\hline Rata - Rata & $\mathbf{2}$ & $\mathbf{1 4 , 3 \%}$ & $\mathbf{6}$ & $\mathbf{4 2 , 9 \%}$ & $\mathbf{1 0 , 8}$ & $\mathbf{7 7 , 1 \%}$ & $\mathbf{1 2}$ & $\mathbf{8 5 , 7 \%}$ \\
\hline
\end{tabular}

Tabel 2.Hasil Observasi Aspek Kemandirian Belajar

Berdasarkan analisis data yang sudah disajikan diatas ditemukan bahwa Kemandirian Belajar sebelum penelitian adalah sebesar 14,3\%, sedangkan setelah siklus 3 pengimplementasian Strategi Blended Learning adalah sebesar $85,7 \%$. Apabila dijabarkan berdasar kritera-kriterianya dapat dijabarkan sebagai berikut: $85,7 \%$ mahasiswa mampu mengambil inisiatif untuk mendiagnosa kebutuhan belajarnya, $85,7 \%$ mahasiswa mampu memformulasikan tujuan belajarnya, $92,9 \%$ mahasiswa mampu mengidentifikasi sumber belajarnya, $85,7 \%$ mahasiswa mampu untuk memilih dan mengimplementasikan strategi belajar yang cocok untuknya, serta 78,6\% mahasiswa mampu mengevaluasi hasil belajarnya. Sehingga dapat dinyatakan bahwa terjadi peningkatan kemampuan mahasiswa untuk belajar mandiri antara sebelum implementasi Strategi Blended Learning dan setelah pengimplementasian Strategi Blended Learning (siklus 1, siklus 2, dan siklus 3).

\section{Aspek Critical Thinking}

Terdapat 13 kriteria yang digunakan untuk mengukur aspek Critical Thinking mahasiswa. Kriteria-kriteria tersebut kemudian digunakan sebagai pedoman untuk menilai jumlah mahasiswa yang mempunyai kemampuan Berpikir Kritis antara sebelum penelitian, penelitian siklus 1, penelitian siklus 2, dan penelitian siklus 3 .

\begin{tabular}{|c|c|c|c|c|c|c|c|c|}
\hline \multirow{2}{*}{ KRITERIA } & \multicolumn{2}{|c|}{ Pra-PTK } & \multicolumn{2}{|c|}{ Siklus 1} & \multicolumn{2}{|c|}{ Siklus 2} & \multicolumn{2}{|c|}{ Siklus 3} \\
\hline & $\sum$ & $\%$ & $\sum$ & $\%$ & $\sum$ & $\%$ & $\sum$ & $\%$ \\
\hline 1. Berpikiran terbuka & 4 & $28,6 \%$ & 10 & $71,4 \%$ & 13 & $92,9 \%$ & 13 & $92,9 \%$ \\
\hline $\begin{array}{l}\text { 2. Mengambil sikap } \\
\text { ketika bukti dan } \\
\text { alasan sudah cukup }\end{array}$ & 2 & $14,3 \%$ & 7 & $50,0 \%$ & 10 & $71,4 \%$ & 12 & $85,7 \%$ \\
\hline $\begin{array}{l}\text { 3. Mempertimbangkan } \\
\text { keseluruhan situasi }\end{array}$ & 2 & $14,3 \%$ & 7 & $50,0 \%$ & 12 & $85,7 \%$ & 12 & $85,7 \%$ \\
\hline $\begin{array}{l}\text { 4. Membekali diri } \\
\text { dengan informasi }\end{array}$ & 2 & $14,3 \%$ & 7 & $50,0 \%$ & 12 & $85,7 \%$ & 12 & $85,7 \%$ \\
\hline $\begin{array}{l}\text { 5. Mencari } \\
\text { kebenaran/keakurat } \\
\text { an sebanyak- } \\
\text { banyaknya }\end{array}$ & 2 & $14,3 \%$ & 7 & $50,0 \%$ & 13 & $92,9 \%$ & 13 & $92,9 \%$ \\
\hline 6. Menyelesaikan & 2 & $14,3 \%$ & 7 & $50,0 \%$ & 12 & $85,7 \%$ & 12 & $85,7 \%$ \\
\hline
\end{tabular}


Jurnal Pendidikan Akuntansi Indonesia, Vol. XI, No. 2, Tahun 2013

Annisa Ratna Sari

$32-43$

\begin{tabular}{|c|c|c|c|c|c|c|c|c|}
\hline \multirow{2}{*}{ KRITERIA } & \multicolumn{2}{|c|}{ Pra-PTK } & \multicolumn{2}{|c|}{ Siklus 1} & \multicolumn{2}{|c|}{ Siklus 2} & \multicolumn{2}{|c|}{ Siklus 3} \\
\hline & $\sum$ & $\%$ & $\sum$ & $\%$ & $\sum$ & $\%$ & $\sum$ & $\%$ \\
\hline $\begin{array}{l}\text { masalah dengan } \\
\text { sistematis dan } \\
\text { menyeluruh }\end{array}$ & & & & & & & & \\
\hline $\begin{array}{l}\text { 7. Mencari alternatif- } \\
\text { alternatif }\end{array}$ & 2 & $14,3 \%$ & 7 & $50,0 \%$ & 10 & $71,4 \%$ & 13 & $92,9 \%$ \\
\hline $\begin{array}{l}\text { 8. Mencari } \\
\text { alasan/sebab }\end{array}$ & 2 & $14,3 \%$ & 7 & $50,0 \%$ & 13 & $92,9 \&$ & 13 & $92,9 \%$ \\
\hline $\begin{array}{l}\text { 9. Mencari pernyataan } \\
\text { yang jelas dari } \\
\text { sebuah } \\
\text { permasalahan } \\
\end{array}$ & 2 & $14,3 \%$ & 7 & $50,0 \%$ & 12 & $85,7 \%$ & 12 & $85,7 \%$ \\
\hline $\begin{array}{l}\text { 10. Mengingat-ingat } \\
\text { hal yang } \\
\text { utama/mendasar }\end{array}$ & 2 & $14,3 \%$ & 7 & $50,0 \%$ & 12 & $85,7 \%$ & 12 & $85,7 \%$ \\
\hline $\begin{array}{l}\text { 11. Mempergunakan } \\
\text { sumber yang } \\
\text { kredibel dan } \\
\text { menyebutkannya }\end{array}$ & 4 & $28,6 \%$ & 10 & $71,4 \%$ & 12 & $85,7 \%$ & 12 & $85,7 \%$ \\
\hline $\begin{array}{l}\text { 12. Berusaha relevan } \\
\text { dengan ide utama }\end{array}$ & 2 & $14,3 \%$ & 7 & $50,0 \%$ & 12 & $85,7 \%$ & 12 & $85,7 \%$ \\
\hline $\begin{array}{l}\text { 13. Sensitif terhadap } \\
\text { perasaan, tingkat } \\
\text { pengetahuan, dan } \\
\text { tingkat kemampuan } \\
\text { orang lain }\end{array}$ & 7 & $50,0 \%$ & 10 & $71,4 \%$ & 13 & $92,9 \%$ & 13 & $92,9 \%$ \\
\hline Rata - rata & 2,7 & $19,3 \%$ & 7,7 & $55,0 \%$ & 12 & $85,7 \%$ & 12,4 & $88,6 \%$ \\
\hline
\end{tabular}

Tabel 3.Hasil Observasi Aspek Critical Thinking

Berdasarkan analisis data yang sudah disajikan diatas ditemukan bahwatingkat Critical Thinking mahasiswa sebelum penelitian adalah sebesar 19,3\%, sedangkan setelah siklus 3 pengimplementasian Strategi Blended Learning adalah sebesar 88,6\%. Apabila dijabarkan berdasar kritera-kriterianya dapat dijabarkan sebagai berikut: 92,9\% mahasiswa berpikiran terbuka, $85,7 \%$ mampu mengambil sikap ketika bukti dan alasan sudah cukup, 85,7\% mampu mempertimbangkan keseluruhan situasi, $85,7 \%$ mampu membekali diri dengan informasi, 92,9\% mahasiswa mampu mencari kebenaran/keakuratan sebanyak-banyaknya, $85,7 \%$ mahasiswa mampu menyelesaikan masalah dengan sistematis dan menyeluruh, 92,9\% mahasiswa mampu mencari alternatif-alternatif, 92,9\% mahasiswa mampu mencari alasan/sebab, 85,7\% mampu mengingat-ingat hal yang utama/mendasar, $85,7 \%$ mahasiswa mampu mempergunakan sumber yang kredibel dan menyebutkannya, serta 92,9\% sensitif terhadap perasaan, tingkat pengetahuan dan tingkat kemampuan orang lain. Sehingga dapat dinyatakan bahwa terjadi peningkatan kemampuan mahasiswa untuk berpikir kritis antara sebelum implementasi 
Strategi Blended Learning dan setelah pengimplementasian Strategi Blended Learning (siklus 1, siklus 2, dan siklus 3).

\section{Implementasi Strategi Blended Learning}

Di dalam pengimplementasian strategi Blended Learning, mahasiswa diberi penilaian untuk penugasan, partisipasi di kelas dan diskusi kelompok, serta nilai UAS.Kemudian dibuat pengelompokan mahasiswa dalam 3 kelompok untuk memudahkan pengelompokan mahasiswa berdasarkan ketuntasannya. Standar ketuntasan ditetapkan sebesar 75 .

\begin{tabular}{|c|c|c|c|c|c|c|}
\hline \multirow{3}{*}{ Komponen Penilaian } & \multicolumn{5}{|c|}{ Nilai } & \multirow{3}{*}{$\underset{\text { Mahasiswa }}{\sum \text { Total }}$} \\
\hline & \multicolumn{3}{|c|}{ Tidak Tuntas } & \multicolumn{2}{|c|}{ Tuntas } & \\
\hline & Nilai 0 & $\begin{array}{c}\text { Nilai } \\
1,0-74,9\end{array}$ & $\%$ & $\begin{array}{c}\text { Nilai } \geq \\
\mathbf{7 5 , 0}\end{array}$ & $\%$ & \\
\hline $\begin{array}{c}\text { 1. Rata-rata Nilai } \\
\text { Tugas dan } \\
\text { Partisipasi Siklus } 1\end{array}$ & 1 & 5 & $42,9 \%$ & 8 & $57,1 \%$ & 14 \\
\hline $\begin{array}{c}\text { 2. Rata-rata Nilai } \\
\text { Tugas dan } \\
\text { Partisipasi Siklus } 2\end{array}$ & 1 & 1 & $14,3 \%$ & 12 & $85,7 \%$ & 14 \\
\hline $\begin{array}{l}\text { 3. Rata-rata Nilai } \\
\text { Tugas dan } \\
\text { Partisipasi Siklus } 3\end{array}$ & 1 & - & $7,1 \%$ & 13 & $92,9 \%$ & 14 \\
\hline 4. Nilai UAS & 1 & 2 & $21,4 \%$ & 11 & $78,6 \%$ & 14 \\
\hline
\end{tabular}

Tabel 4.Hasil Observasi Aspek Prestasi Belajar

Berdasarkan analisis data yang sudah disajikan diatas dapat dinyatakan bahwa Strategi Pembelajaran Blended Learning tidah hanya dapat meningkatkan Kemandirian Belajar dan kemampuan Critical Thinking mahasiswa, akan tetapi juga dapat meningkatkan Prestasi Belajar mahasiswa. Dalam siklus 1, persentase jumlah mahasiswa yang mempunyai rata-rata nilai tugas dan partisipasi siswa lebih besar sama dengan 75 adalah sebesar 57,1\%. Keadaan ini meningkat kembali pada implementasi siklus 2 menjadi $85,7 \%$ dan siklus 3 menjadi 92,9\%. Peningkatan yang signifikan baru terlihat pada siklus ke-3 dikarenakan mahasiswa masih belum familiar dengan strategi Blended Learning ini. Sehingga membutuhkan waktu yang cukup untuk beradaptasi dengan strategi pembelajaran yang baru.

Berdasarkan capaian nilai UAS, terdapat 11 orang $(78,6 \%)$ mahasiswa yang mendapatkan skor lebih besar sama dengan 75 dari total mahasiswa sebanyak 14 orang. Dari 3 orang yang belum tuntas tersebut, 1 orang tidak mengikut UAS, 1 orang mendapatkan skor 65 dan 1 orang mendapatkan skor 70. Di luar faktor penilaian aspek kognitif tersebut, bisa dijelaskan bahwa pelaksanaan Strategi Belajar Blended Learning cukup sukses dengan adanya dukungan teknologi dan koneksi internet yang memadai. 


\section{PENUTUP}

Berdasarkan hasil penelitian dan pembahasan yang telah diuraikan, dapat diambil simpulan bahwa pengimplementasian Strategi Pembelajaran Blended Learning dapat meningkatkan Kemandirian Belajar dan kemampuan Critical Thinking mahasiswa, serta mampu meningkatkan Prestasi Belajar mahasiswa. Diluar kesuksesan pelaksanaan Strategi Blended Learning diatas, kita perlu menyadari bahwa strategi ini relatif baru di Indonesia, sehingga masih jarang dipakai. Hendaknya pengajar memperhatikan dukungan teknologi dan koneksi internet yang memadai sehingga dapat memperlancar implementasi startegi pembelajaran ini. Kesiapan teknologi dan koneksi internet yang memadai ini perlu dilihat baik dari segi tenaga pengajar maupun peserta didiknya. Tanpa adanya dukungan yang memadai, sebaiknya tenaga pengajar lebih memilih penggunaan pembelajaran berbasis kelas (klasikal). Selain itu, pengajar juga perlu mempertimbangkan faktor biaya. Guna menekan faktor biaya, para tenaga pengajar dapat memanfaatkan tawaran aplikasi yang bebas biaya di internet sehingga tidak perlu membangun sistem informasi yang kompleks sendiri.

\section{E. DAFTAR PUSTAKA}

Ahmad Faizal. (2011). Upaya Peningkatan Keaktifan Siswa Melalui Implementasi Blended Learning Pada Pembelajaran Biologi Kelas XI SMAIT Nur Hidayah Kartasura. Skripsi: FKIP UNS.

Carol B. McKnight. (2000). Teaching Critical Thinking through Online Discussions. Educause Quarterly Number 4 2000. Diakses melalui http://eac595b.pbworks.com/f/macknight+2000+questions\%5B1\%5D.pdf tanggal 16 Maret 2012.

David Hopkins. (2011). Panduan Guru: Penelitian Tindakan Kelas. Yogyakarta: Pustaka Pelajar.

Irzan Tahar dan Enceng.(2006). Hubungan Kemandirian Belajar dan Hasil Belajar pada Pendidikan Jarak Jauh.Jurnal Pendidikan Terbuka dan Jarak Jauh, Volume. 7, Nomor 2, September 2006, 91-101.

Kana Hidayati dan Endang Listyani.(2010). Pengembangan Instrumen Kemandirian Belajar Mahasiswa. Diakses melalui: http://staff.uny.ac.id/sites/default/files/penelitian/Kana\%20Hidayati,\%20M. Pd./Pengembangan\%20Instrumen.pdf tanggal 17 Maret 2012.

Maria D. Avgerinou. (2008).Blended Collaborative Learning for Action Research Training.Journal of Open Education volume 4 No.1, 2008.

Murray Fisher, Jennifer King, dan Grace Tague.(2001). Development of a SelfDirected Learning Readiness Scale for Nursing Education. Nurse Education Today 21, p. 516-525. Diakses melalui: http://ccnmtl.columbia.edu/projects/pl3p/selfdirected\%20learning\%20scale\%20for\%20nurses.pdf tanggal16 Maret 2012. 
Jurnal Pendidikan Akuntansi Indonesia, Vol. XI, No. 2, Tahun 2013

Annisa Ratna Sari

$32-43$

Ozgen Korkmaz dan Ufuk Karakus. (2009). The Impact od Blended Learning Model on Student Attitudes Towards Geography Course and Their Critical Thinking Dispositions and Levels. The Turkish Online Journal of Educational Technology - TOJET October 2009 volume 8 Issue 4.

Richard Paul dan Linda Elder. (2008). The Miniature Guide to Critical Thinking Concepts and Tools. California: The Foundation for Critical Thinking Press.

Robert J. Stenberg dan Joan B. Baron.(1985). A Statewide Approach to Measuring Critical Thinking Skills.Educational Leadership October 1985. Diakses melalui http://www.ascd.org/ASCD/pdf/journals/ed_lead/el_198510_sternberg.pdf tanggal 16 Maret 2012.

Suharsimi Arikunto. (2008). Penelitian Tindakan Kelas. Jakarta: PT. Bumi Aksara.

Sugiyono. (2005). Memahami Penelitian Kualitatif. Bandung: Alfabeta. 